\title{
Rummaging in Trotsky's dustbin or What does the left need with history?
}

\section{Document Version}

Accepted author manuscript

Link to publication record in Manchester Research Explorer

\section{Citation for published version (APA):}

Morgan, K. (2003). Rummaging in Trotsky's dustbin or What does the left need with history? Soundings, 23.

\section{Published in:}

Soundings

\section{Citing this paper}

Please note that where the full-text provided on Manchester Research Explorer is the Author Accepted Manuscript or Proof version this may differ from the final Published version. If citing, it is advised that you check and use the publisher's definitive version.

\section{General rights}

Copyright and moral rights for the publications made accessible in the Research Explorer are retained by the authors and/or other copyright owners and it is a condition of accessing publications that users recognise and abide by the legal requirements associated with these rights.

\section{Takedown policy}

If you believe that this document breaches copyright please refer to the University of Manchester's Takedown Procedures [http://man.ac.uk/04Y6Bo] or contact uml.scholarlycommunications@manchester.ac.uk providing relevant details, so we can investigate your claim.

\section{OPEN ACCESS}




\section{Rummaging in Trotsky's dustbin or what does the left need with history?}

One of the memorable images of the Russian revolution is that of the Smolny Institute, Petrograd, the day that the Bolsheviks seized power, where in a room acrid with tobacco fumes and recrimination delegates of the second Congress of Soviets assembled to take up positions on the new turn of events. Confronted with the usurpation of their own authority and what they saw as an affront to democracy, a succession of the Bolsheviks' critics got up to denounce the operation as a conspiracy, abandoning the proceedings pursued by menaces and hoots of derision. The last of them to leave was the Menshevik Julius Martov, once the personal and political intimate of the current master of the situation, Leon Trotsky. Now that counted for nothing, and as he rose to hasten Martov's departure, Trotsky's face was pale and cruel and his voice rang out with cool contempt. 'You are miserable, isolated individuals. You are bankrupt. You have played out your role', he jeered. 'Go where you belong: to the dustbin of history! ${ }^{1}$

In politically misspent youths, or during those educational opportunities which they are now so keen to circumscribe and commodify, one wonders which of Labour's current crop of permanent revisionists savoured this scene in its paperback manifestations of the 1960s and 1970s. In any case, it is Trotsky's invocation of History - upper case, transcendent and as remorseless as Trotsky himself - that I want to locate in a longer line of left-wing thinking so disparate in character as to take in Millbank modernisers as well as the 'unwashed human bodies' in the Smolny Institute. In the colloquial sense, history itself was Trotsky's dustbin, a sort of mouldering rubbish-heap where customs, ideas, leaders, even whole social classes lay discarded, while socialism as prophecy and deliverance turned its face resolutely to the future. In many respects the conception was millenarian and even anti-historical: as Richard Stites and others have pointed out, Bolshevism contained a powerful strain of utopianism of which Trotsky's militarisation of labour was only one of the more draconian expressions. $^{2}$ Nevertheless, if history as the past was rejected, this was in the name of History as process, a master narrative transcending contingencies of time and place, from whose acceptance and understanding the effectiveness of particular events and historical actors derived. It was this historical sense that was seen to distinguish Marxism from the utopian socialists, and on which even the palpable voluntarism of the Bolsheviks based its claimed of irrevocability. If Trotsky could waved aside Martov as a floundering individual, it was in the name not only of the insurgent proletariat, but of the movement of history itself.

Though traditionally it is Marxists who have been most identified with the great determining force of 'Comrade History', theirs was by no means the only variant of socialist teleology. More familiar in Britain, for example, were those Fabian narratives of modernisation which, emerging at the same time as the first British Marxist writings in the 1880s, initially posited the largely unconscious development of collectivism on the basis of the increasing and irreversible complexity of modern industrial society. Sidney Webb, in many respects the quintessential Fabian, was as dismissive as any Marxist of utopian socialism, describing urbanisation, industrial concentration and the 'strict subordination and discipline' of the factory as the necessary concomitants of a modern social order. ${ }^{3}$ Except at a popular level, he also, in common with his Marxist contemporaries, eschewed the language of political 
morality. Rather in the manner of the Russian social democrat Plekhanov, who in the name of 'swim[ing] with the tide of History' upheld the desirability of capitalism as a necessary stage in human progress, Fabians even inclined towards the defence of empire as a necessary step towards 'the dissolution of Frontiers through international industrial organisation': apparently a statist prefiguration of the later promotion of unequal and exploitative power relationships in the necessitarian guise of the global market. ${ }^{4}$ Domestically, the same line of thinking culminated in Webb's proclamation of the 'inevitability of gradualness' at the 1923 Labour Party conference, where the belief in inevitability that linked him with the Bolsheviks was no less significant than the gradualness that set them apart. Seemingly that was to be borne out in the following decade, when as the acknowledged architects of British gradualism the Webbs warmed to the achievements of the Russian revolution and consigned not only Martov but the ousted Trotsky himself to history's dustbin. Conventionally, this attachment has been taken to show the underlying affinity of Fabianism and Stalinism as the self-serving creeds of a new managerial elite. Equally, it revealed their common conception of history as a sort of juggernaut to whose laws of motion all moral critique, and the most basic interests of those who stood in history's way, were all too effectively subordinated.

If it is true, as Tony Wright has argued, that little now remains of this socialism as historicism - the socialism that thought that it had 'cracked the historical code and discovered the laws of social dynamics' - what does remain is socialism as the critique of historicism, and the articulation of values and aspirations irreducible to their historical functionality: in a word, some form of moral or ethical socialism. ${ }^{5}$ Where, however, is such a critique nowadays to be found? A few years ago, some would have said at the heart of New Labour, whose much spun retrieval of an 'ethic' of socialism was seen as having recovered what was essential in the socialist tradition from what was merely contingent and instrumental. No Blair speech was complete without the invocation of these 'timeless' values - community, democracy, liberty, justice, mutual obligation - which not only could not be reduced to transient policy manifestations but frequently bore no obvious relation to them at all. Wright himself was among the most effective exponents of this aspect of New labour politics, appending a new chapter to his book Socialisms in which Blair's claim to have taken Labour 'back to its ethical roots' was fulsomely endorsed. ${ }^{6}$

Overlooking for present purposes the Tartuffian ambiguities of some of Labour's earlier ethical socialists - Geoffrey Foote, for example, mentions in this context not only Morris and Tawney, but Ramsay MacDonald - it is now abundantly clear that none of the hopes invested in New Labour was to be as sorely disappointed as this. It is not just that the delivery of an 'ethical' foreign policy, or of a radically different relationship between government and people, has proved more difficult to deliver than even the most cautious of the government's supporters can have anticipated. What is more remarkable is how routinely the deciding argument for government policy has been that of swimming with the tide of history. From the distribution of wealth, to the regulation of industry and organisation of public services, to international development and the protection of the environment, the banal ethicality of the Third Way has been underpinned by a stern counsel of historical necessity, precluding or determining larger political choices in the name of the law of social dynamics currently hypostatised in the market. Except as a sticky repository of 'values', history itself is less often invoked than the demands of 'change' or of our modern condition, 
for this is not a teleology of the oppressed, fixated on some future millenium, but a modernising rhetoric of the powerful, or at least careful to respect existing relationships of power. In any case, the argument of inexorability is never far away, and in the popular expositions of Blair himself is presented with all the political finesse of a Spitting Image Thatcher chanting 'there is no alternative'.

In his incisive commentary New Labour, New Language? Norman Fairclough cites as one example of the Blairite device of the 'cascade of change' a speech the prime minister gave in 1998 to the Confederation of Business Industries.

We all know this is a world of dramatic change. In technology; in trade; in media and communications; in the new global economy refashioning our industries and capital markets. In society; in family structure; in communities; in life styles. ...

The choice: to let change overwhelm us, to resist it or equip ourselves to survive and prosper in it. The first leads to a fragmented society. The second is pointless and futile, trying to keep the clock from turning. The only way is surely to analyse the challenge of change and to meet it. $^{7}$

As Fairclough comments, by the device of nominalisation, that is the representation the process 'change' as a noun, Blair constructs 'change' and 'us' as separate entities entirely external to each other, so that "we" are confronted with change as effects without agency, rather than being participants in change able to affects its direction'. Probably we might even find ourselves in change's dustbin.

Though the language is in some respects new, its constructions are therefore strangely familiar. In tracing New Labour's historical antecedents, reference is most often made to the modernising Wilson years, to MacDonald's 1920s big tent, or to the 1950s revisionists whose clinching argument was also - until it swung back towards the 1930s - the turning clock. Probably therefore it is simple perversity and bad taste to invoke in this context the Stalinist apologist J.D. Bernal, whom in 1946 another keen observer of linguistic usages, George Orwell, took to task for his claim that the only 'virtuous' actions were 'effective' actions. Nevertheless, reading Blair's speeches suggests that Bernal is not the only social-ist in whom issues of 'power' and 'virtue' can be found inextricably intermingled. 'Right action does not lie in obeying your conscience, or a traditional moral code; right action lies in pushing history in the direction in which it is actually going', Orwell scathingly observed of the so-called Marxist 'sage', and it is difficult to put a more generous construction on Blair's domineering timepiece. ${ }^{8}$ In the sort of linking of 'assumed incompatibilities' that is now inseparably identified with the Third Way, it is fitting that Bernal's essays should have been collected together under a title at once Marxist, 'Orwellian' and somehow vaguely Blairite: The Freedom of Necessity.

Against the freedom of necessity, in whatever guise, perhaps the most valuable resources we have is - in the lower case - history. By this I do not primarily mean the traditional socialist moral code invoked by many of New Labour's critics in contrasting it with its predecessors and reproaching it with the denial of its own parentage. ${ }^{9}$ Still less is it possible to call upon the sort of alternative counsel of necessity that moved Bernal; and one can probably agree with Wright and Giddens that those who believe that it is are, if not exactly 'antiquarian', less engaged than 
they might be with the world we actually live in. In any case, Bernal's type of Marxism was a treacherous and ultimately misanthropic philosophy. Although it had the one advantage over change-cascaders of apparently identifying itself with history's present casualties, thus containing elements of an ethical critique of capitalism even despite its pretended scientism, the projection of necessitarian Marxism onto ostensibly socialist societies proved both morally and politically the most disastrous of the errors committed by the twentieth-century left. ${ }^{10}$ What we therefore need instead, and have always needed, is not History as a relentless tide or ticking clock, but history as the refusal of historicism, a history that is dissenting, oppositional and above all sceptical of the language of necessity. Though nostalgia should be held in check, it should not even exclude the pointless and the futile machine breakers, war resisters, moral reformers - whom Edward Thompson once referred to as the 'casualties' of history, and of whom it is often difficult to tell whether they arrived too early for their parts or too late. In a word, we need a history that cannot be nominalised as if its own active agent, entirely beyond our merely human control. ${ }^{11}$

In recovering such a history, we do not exactly have to start from scratch. On the contrary, such a history, or compendium of histories, provides one of the outstanding intellectual achievements of the post-war British left, and a resource and inheritance that remains substantially intact despite the political crisis of Marxism. By this I do not mean that these historians provided a corpus of writings that is sacrosanct, for self-evidently this is not the case: from almost every possible perspective, ranging from feminism and post-structuralism to high politics and a sort of re-invigorated Namierism, probably no body of writing has been at once so influential and so much the focus of academic revisionism. Nevertheless, what can be traced almost from the earliest years of the CPGB historians' group, through to the later manifestations of the History Workshop movement, is a concept of history as comprising both the choice and the conflict between alternatives, so that 'change' is never wholly pre-determined, but susceptible to the pressure of human agency.

If this, like Bernalism, originated in Marxism, it was nevertheless based on a very different reading of the same texts. With one or two exceptions, like the economist Maurice Dobb, what both activists and historians tended to take from Marxism in Britain was not a teleology overriding moral considerations, but a rhetoric and legitimation of social conflict that was usually described if not explained at the level of human agency. It is in this sense that historians like Thompson and Christopher Hill were accused of 'culturalism' or even of a 'retreat' into moralism. In his essay on the comunist party historians, Bill Schwarz rightly noted the group's emphasis on 'formative, heroic or democratic moments of people's history', but might have added that these almost invariably were moments of resistance or opposition: often fugitive - the Ranters were even claimed by critics not really to have existed - always embattled and dissenting, and only fleetingly or obliquely identified with the exercise of political power. ${ }^{12}$ This was even true of the account of the English revolution which Hill intruded into Marxist historiography, for what Hill described in a whole series of were effectively the heroic precursors of bourgeois society, not the political and commercial fruits of the revolution itself. Indeed, with the notable exception of Eric Hobsbawm, in some respects the most rigorous and least suggestible of the group, it is extraordinary that the British Marxist historians produced no sustained 
account of the indigenous industrial transformation on which the whole intellectual edifice of historical materialism was so largely built.

Instead, the group's most famous monument was Thompon's classic work of 1963, The Making of the English Working Class. In Marxist terms, the book can only be described as highly unorthodox. Formally it delineates a process of class formation in more or less conventional terms, or at least conforming to the underlying trajectories of teleological Marxism. Nevertheless, in Thompson's account the teleology not only appears as contingent on national specificities of politics and culture, but ends as abruptly as the book itself does, in the 1830s. Probably there is not much to be said for teleologies that judder to a halt without obvious prospect of a resolution, but as a politically engaged historian Thompson's purpose appears to have been rather different. Writing in an age in which the 'end of ideology' prefigured the 'end of history'; in which the 'assumed incompatibilities' of the Third Way could be found in the composite figure of Mr Butskell; in which 'affluence' and apathy, as today, were seen as interdependent; when great-power politics masqueraded under the language of morality; and when Thompson was one of those who had only recently disentangled himself from Stalinism-Bernalism; writing in age like this, what Thompson's Making affirmed were notions of agency, human dignity and dissent, and those 'timeless' values - liberty, mutuality, social justice - which then as now amounted to nothing except so far as realised in time and place. What Thompson celebrated was a sort of defiance of the logic of necessity, 'not a revolutionary challenge, but a resistance movement, in which both the Romantics and the Radical craftsmen opposed the annunciation of Acquisitive Man', and in so doing created the 'most distinguished popular culture England has known'. ${ }^{13}$ There is a little sense here of celebrating history as a forward march; and though Thompson has, with some justification, been accused of romanticism, moralism and a preoccupation with activist minorities, the very last word that can be applied to his historical method is 'vanguardist'. ${ }^{14}$ Though usually thought of as a catalyst for history from below, The Making of the English Working Class was just as profoundly conceived as a sort of history against the stream.

Forty years on, we would not write that history in quite the same way. As well as Thompson's overriding concern with class, we would want to explore more closely other forms of cleavage and identity such as gender and ethnicity, and we would want to consider how class itself was constructed in ways that were not - to recall the words of the book's opening sentence - necessarily 'unlimited'. ${ }^{15}$ This also means that we are likely to take a less celebratory view of activist minorities, who were not always free from their own forms of condescension, and to take in wider forms of experience than those contributing to a picture of class formation. Nevertheless, when all these particular arguments have been made, the larger lesson remains of history as a narrative of agency and alternatives as well as structuration. If it stands as a refusal of determinism in the past, then it also undermines that fatalism about the future to which not the fact but the ideology of globalisation has in recent years given such encouragement.

What those alternatives might be is perhaps of less basic significance than the simple affirmation of pluralism and contestedness, both in our readings of the past and our understanding of the present. From a social-democratic perspective that is anything but hostile to the breach with 'old' Labour, David Marquand has described the issue 
with impeccable cogency. 'The real meaning of new Labour's modernisation rhetoric', he writes,

is that Blair and his associates have absorbed some of the central tenets of the neo-liberalism of the recent past - the propositions that there is one modern condition ... that the renascent capitalism of our day embodies that condition; and that resistance to it is futile. ... These propositions ... are designed to justify what might otherwise appear to be evils by an appeal to a higher power - no longer God, but history.

They offer, Marquand goes on, a route out of the realm of choice and moral argument and into the realm of necessity.

As such, they are a negation of the commitment to human autonomy which has differentiated the social-democratic tradition from mechanistic Marxism on the one hand and High Tory traditionalism on the other. ${ }^{16}$

Autonomy is a relative concept, and no serious history can be written that is a story only of autonomous human agency. However, against the present-day historicism that can only conceive of freedom as the recognition of market necessities, it is precisely for that reminder of our own autonomy that a genuine sense of history, past and continuing, remains of such fundamental significance for the left.

\footnotetext{
1 John Reed, Ten Days that Shook the World (London, 1926), p. 79; Isaac Deutscher, The Prophet Armed. Trotsky: 1879-1921 (Oxford, 1970 edn), pp. 313-14; Israel Gertzler, Martov. A political biography of a Russian Social Democrat (Cambridge, 1967), p. 162.

2 Richard Stites, Revolutionary Dreams. Utopian vision and experimental life in the Russian revolution (New York, 1989), pp. 37-57.

3 Sidney Webb, Socialism: true and false (London, 1894).

4 See Alan McBriar, Fabian Socialism and English Politics 1884-1918 (Cambridge, 1966), ch. 5; also Andrzej Walicki, Marxism and the Leap to the Kingdom of Freedom. The rise and fall of the communist utopia (Stanford, Cal., 1995), pp. 228-46.

5 Tony Wright, Socialisms: old and new (London, 1996 edn), p. 136.

6 See the new prefaces by Blair and Wright, pp. ix-xi, and pp. 124-49.

7 Norman Fairclough, New Labour, New Language? (London, 2000), pp. 25-7.

8 Sonia Orwell and Ian Angus (eds), The Collected Essays, Journalism and Letters of George Orwell. Volume four. In front of your nose 1945-1950 (Harmondsworth, 1970 edn), pp. 186-7.

9 See for example Royden Harrison, New Labour as Past History (Nottingham, 1996).

10 See e.g. the recent discussion in Lawrence Wilde, Ethical Marxism and its Radical Critics (Basingstoke, 1998).

11 See Fairclough, New Labour, New Language?

12 Bill Schwartz, "'The people" in history: the Communist Party Historians' Group, 1946-1956' in Richard Johnson et al (eds), Making Histories. Studies in history-writing and politics (London, 1982),

13 E.P. Thompson, The Making of the English Working Class (London, 1963), pp. 831-2.

14 See Steven Fielding, "New" Labour and the "new” labour history', Mitteilungsblatt des Instituts für soziale Bewegungen, 27 (2002), pp. 41-3.

15 'That the number of our Members be unlimited' was the first rule of the London Corresponding Society, from which Thompson took the title of his first chapter.

16 David Marquand, 'Premature obsequies. Social democracy comes in from the cold' in Andrew

Gamble and Tony Wright (eds), The New Social Democracy (1999), pp. 12-13.
} 